\title{
In Search of Intellectual Stimulation: Understanding the Relationship Between Motivation, Deep Learning and Stimulation in the Higher Education Classroom
}

\section{Sandeep Chowdhry ${ }^{1}$, Renata Osowska ${ }^{2}$}

${ }^{1}$ Lecturer, School of Engineering, Edinburgh Napier University, Scotland, U.K

${ }^{2}$ Lecturer, School of Business, Edinburgh Napier University, Scotland, U.K.

E-mail: s.chowdhry@napier.ac.uk,r.osowska@napier.ac.uk

Published Online: June 28, 2017

The Author(s) 2017. This article is published with open access at www.chitkara.edu.in/publications
Abstract: One of the key educational notions measured in the National Student Survey (NSS) is intellectual stimulation. This study aimed to find out Higher Education (HE) engineering students' views of intellectual stimulation with a focus on its measurement and supporting its increase within the classroom environment. A quantitative questionnaire acted as a data gathering instrument. The sample comprised 128 students from Edinburgh Napier University (ENU), Scotland. The survey findings showed a positive correlation and positive agreement between the intellectual stimulation (IS), intrinsic motivation (IM) and deep learning approach (DLA) scales. The students' feedback suggests that implementation of the new intellectual scale based teaching and learning strategy is useful in intellectually stimulated the students and encouraged them to adopt deep learning approach. The findings suggest the design of an intellectually stimulating environment in HE classroom, should consider students' learning styles, challenge students, allow the provision of timely feedback and provide opportunities to encourage independent thought. Further, the research suggests, the studied institution should encourage staff to consider the intellectual stimulation scale when constructively aligning learning and teaching with an assessment.

Keywords: Intellectual stimulation, problem based learning, Active learning, Constructivism, Academic staff development

\section{INTRODUCTION}

Intellectual stimulation is one of the criteria used in the National Student Survey (NSS) in the UK. It is an influential source of public information about higher education and gives students a powerful collective voice to help shape the future of their course and their university or college. Thus, supporting
Journal on Today's Ideas Tomorrow's Technologies, Vol. 5, No. 1, June 2017 pp. 9-29

CHITKARA 司 
Chowdhry, S. intellectual stimulation of students has become a major concern to Edinburgh Osowska, R. Napier University's undergraduate modules (Edinburgh Napier University, 2013). For instance, in the School of Engineering, there is a steady decrease in the students' positive response to the question, 'The course is intellectually stimulating' (NSS result 2013-88\%, NSS result 2014- 86\%, NSS result 2015$83 \%$ and NSS result 2016- $83 \%$ ). While the NSS survey takes place each year with only final year students, the-University have been trying to increase their scores in the inquiry by finding out, through student feedback on every module taught, what issues students have in each area of their studies earlier in their programme.

Terms such as deep learning approach and intrinsic motivation are well understood among the academics. The aim of this paper is to cast some light into the educator's understanding of intellectual stimulation as a criterion applied for module evaluation with the deep learning approach and intrinsic motivation. In particular, the current study has three objectives: 1) to determine the relationship between the students' perceptions on intrinsic motivation, intellectual stimulation and deep learning approach, 2) to find out what intervention strategies lecturers can put in place to support students feeling 'intellectually stimulated', 3) assess the effectiveness of the new proposed teaching and learning strategy, 4) propose recommendation for using 'intellectual stimulation' as an evaluation criterion for teaching and learning in higher education.

\section{LITERATURE REVIEW}

Intellectual stimulation is a topic that stems from the search for exploration, challenge and individual development. However, there is lack of clarity about the meaning of this elusive idea in the academic literature. The definition appears to vary between disciplines and it is even more problematic if applied across them. For intellectual stimulation, there are various definitions to choose from, depending on the discipline applied. For example, Shahzad and Zareen (2011) identified two definitions in transformational leadership and psychology that are viable for this study: first, 'as the degree of the people's encouragement to be creative in looking at old problems in new ways, by creating an environment that is tolerant'. According to the second definition, intellectual stimulation is 'questioning old assumptions and the status quo' (Hetland and Sandal, 2003). However, for this article the focus will be on the literature on education with particular interest in the Higher Education (HE) context. The study of intellectual stimulation is still scarce; and, there is a need to conduct more research on its influence in the classroom environment (Bolkan, Goodboy and 
Griffin, 2011). The concept is again usually linked to the role of teachers as transformational leaders (Bolkan and Goodboy, 2010)(Bolkan, Goodboy and Griffin, 2011). Although, Bolkan and Goodboy (2010) verified that intellectual stimulation has the ability to influence student learning, scholars have yet to find out the mechanisms of that interaction.

Since the lack of measurement of intellectual stimulation in the literature (Bolkan and Goodboy, 2012), the transformational leadership includes the students' involvement in the process of intellectual stimulation, acknowledging the benefits of deep approaches to learning (Entwistle, 1988). Specifically, Bolkan and Goodboy (2010) suggest that 'teachers who promote intellectual stimulation empower students and promote both cognitive and affective learning'. Nevertheless, the impact of intellectual stimulation on learning outcomes enhancement depend on the role of intrinsic motivation. Based on an extensive literature review, Wolters (1998) argued that intrinsically motivated students persist in their tasks longer and adopt deep learning approach in their studies, which also develop their critical thinking. In addition, the self-improvement (which could be associated with intrinsic motivation) has been associated with 'deep-processing cognitive learning strategies and self-regulation strategies (for example, self-testing while reading and monitoring one's understanding of class lectures)' (Bolkan, Goodboy and Griffin, 2011). Finally, intrinsic motivation has been associated with 'cognitive engagement and classroom performance by way of self-regulation and the use of adaptive strategies for studying (for example, elaborating on class material and organizing class notes)' (Bolkan, Goodboy and Griffin, 2011). Therefore, based on this review, the association between intellectual stimulation and intrinsic motivation has the potential to develop deep learning approach among students.

The research on deep and surface approaches mainly aims at the students' basic approaches to their schoolwork (Entwistle, Hanley and Hounsell, 1979).Students who use a deep approach to learning look for meaning in the matter being studied 'relating that 'to other experiences and ideas with a critical approach', whereas students who apply a surface approach depend on 'rote-learning and memorization in isolation to other ideas' (Duff, 2004, p.57).Understanding the way students approach their studying can predict their performance since research has revealed an association between deep approach to learning and 'higher quality learning outcomes' (Prosser and Trigwell, 1999, p.12). Further, there is a positive relation between the general academic performance and the deep approach to learning (Duff, 2003).

Following this line of argument, the findings of Bolkan, Goodboy and Griffin (2011) suggest that challenging students in the classroom may be the
In Search of Intellectual Stimulation: Understanding the Relationship Between Motivation, Deep Learning and Stimulation in the Higher Education Classroom 
Chowdhry, S. Osowska, R.

most influential aspect of intellectual stimulation when it comes to fostering intrinsic motivation, and imply that teachers who push students to know the course material well and who help students to be the best they can be also encourage students to improve their motives for studying. Furthermore, the direct relationship between encouraging independent thought and students' deep approach to studying is more important than the interactive learning style.

To find out the contributing causes of intellectual stimulation to learning, there is a need to consider number of factors in teaching and learning practice and contribute to related literature. Therefore, the aim of this study is to explore the association between intellectual stimulation, intrinsic motivation and deep learning approach relative to the students' perception.

\section{Research Design and Context}

The research took place within the first and third year engineering module which uses a problem-based learning (PBL) method. A quantitative students' feedback is used in examining the relationship and association between the intellectual stimulation, intrinsic motivation and deep learning

The study included 128 engineering students' at ENU. The students were from various departments at the university, and some students came as direct entry through an international exchange programme. The module teaching included face to face sessions and instructions on virtual learning environment (VLE).

To study the issue, the conceptual framework is formed with the use of: student intellectual stimulation scale developed by Bolkan and Goodboy (2010), the shortened experiences of teaching and learning questionnaire (SETLQ) (ETL Project, 2005) and the manual for the use of the motivated strategies for learning questionnaire (MSLQ) (Pintrich et all, 1991).

A quantitative feedback questionnaire collected data on the students' perceptions of intellectual stimulation, intrinsic motivation and deep learning approach. The feedback questionnaire included three core behaviours of intellectual stimulation, i.e. interactive teaching style (ITS) with 4 questions, challenging students (CS) with 3 questions, encouraging independent thought (EIT) with 3 questions and 4 questions on intrinsic motivation (IM). In addition, there were 9 questions on a deep learning approach (DLA) (Appendix 1). Parametric tests determined a statistically significant correlation and a non-parametric test helped in finding the measure of agreement between the intellectual stimulation, intrinsic motivation and deep learning approach. The research used the statistical software, SPSS 20.0 (academic version) to perform the data analysis.

A reliability coefficient of Cronbach's alpha determined the reliability of the questionnaire. Alpha reliabilities for the total scale and subscales are: summed scale $=0.90$ (mean, $\mathrm{M}=87.51$, standard deviation, $\mathrm{SD}=17.31$ ); interactive teaching style $=0.79(\mathrm{M}=14.40, \mathrm{SD}=4.22)$; challenging students $=0.86$ 
$(\mathrm{M}=12.14, \quad \mathrm{SD}=4.06)$; encouraging independent thought $=0.80(\mathrm{M}=12.49$, $\mathrm{SD}=3.89)$; deep learning approach measurement); intrinsic motivation measurement $=0.65(\mathrm{M}=18.77, \mathrm{SD}=4.13)$. The lower limit of Cronbach's alpha coefficient of 0.60 is acceptable (Hair et all, 2009). Therefore, the reliability analysis shows a good consistency of the entire scale and the subscales of the measurement instrument. Also, a reliable measuring instrument is valid too. (Gupta and Kapoor, 2007). There are acceptable number of questions in each feedback questionnaire to collect all the relevant information needed to find the effectiveness of the use of education technology tools in improving the students learning experience in the module. Data analysis determined the relationship between the intellectual stimulation, intrinsic motivation and deep learning approach. The first research question (RQ) is

RQ1: Whether there is a relation between students' perceptions of the intellectual stimulation and the intrinsic motivation?

The aim of this RQ is to find if there is a relationship between the intellectual stimulation and the intrinsic motivation measurements. To answer this RQ, the correlation between the intellectual stimulation and the intrinsic motivation variables is determined using Pearson's product-moment correlation test, and Kendall's tau-b test determines the measure of agreement between the individual elements of IS and IM.

The second RQ is

RQ2: Is there a relation between the students' perception on the intellectual stimulation and the deep learning approach measurements?

The aim of this RQ is to find a relation between the intellectual stimulation and the deep learning approach measurements. To answer this RQ, the students' feedback data on Pearson's product-moment correlation test and the measure of agreement between the individual elements of IS and DLA is determined by Kendall's tau-c test.

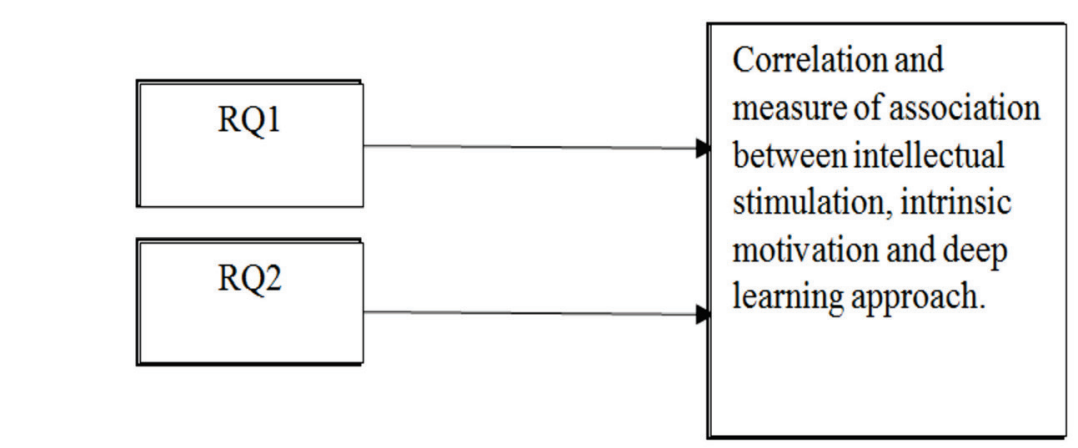

Figure1: Research Design Diagram
In Search of Intellectual Stimulation: Understanding the Relationship Between Motivation, Deep Learning and Stimulation in the Higher Education Classroom 


\section{Chowdhry, S. ANALYSIS OF DATA AND INTERPRETATION OF RESULTS}

intellectual stimulation and intrinsic motivation?

To answer this RQ, the intellectual stimulation scale of Bolkan and Goodboy (2010) is used to gather data on the students' perception on the intellectual scale. Similarly, MSLQ (Pintrich et all, 1991) is used to gather data on students' perceptions on the intrinsic motivation. First, Pearson's product-moment correlation coefficient is used to explore the correlation between the IS and IM scales. Table 1 reports the correlation. The result shows a statistically significant $(\mathrm{p}=0.002)$ and a weak positive correlation. Pearson's product-moment correlation coefficient is, $\mathrm{r}=0.371$ with $\alpha=0.05(-1 \leq \mathrm{r} \leq 1$; where -1 means a strong negative correlation, 0 means no correlation and 1 means a strong positive correlation). It showed that higher IS scale is associated with higher IM scale.

Table 1: Correlation between the intellectual stimulation and the intrinsic motivation using Pearson's Product-Moment test

\begin{tabular}{|l|l|l|}
\hline \multicolumn{2}{|l|}{} & \multicolumn{2}{c|}{ Intrinsic Motivation } \\
\hline $\begin{array}{l}\text { Intellectual } \\
\text { Stimulation }\end{array}$ & Pearson Correlation & $.371^{* *}$ \\
\cline { 2 - 3 } & Sig. (2-tailed) & .002 \\
\hline$* *$ Correlation is significant at the 0.01 level (2-tailed). \\
\hline
\end{tabular}

Second, Kendall's tau-b test is used to find the measure of agreement between the individual elements of IS and IM scales, as both are ordinal scales with the same number of response choices. The results show a statistically significant $(p<\alpha)$ and a weak positive agreement between some elements of IS and IM scales. Kendall's tau-b agreement coefficient for a pair of elements is shown in Table 2, with $\alpha=0.05(-1 \leq$ $\tau \leq 1$; where -1 means a perfect disagreement, 0 means both variables are independent, and 1 means a perfect agreement). It shows that IM3 element is in positive agreement with CS1, CS2, EIT1 and EIT2 (Appendix 1) elements of intellectual stimulation scale. Whereas, ITS2, ITS3, CS3 and EIT3 (Appendix 1) are not associated with any of the items of the IM scale. 
Table 2: Correlation between the intellectual stimulation scale data and the intrinsic motivation data using Kendall's tau-b test

\begin{tabular}{|l|l|l|l|l|}
\hline & IM1 & IM2 & IM3 & IM4 \\
\hline ITS1 & $0.207^{\mathrm{a}}(\mathrm{P}=0.046)$ & & & \\
\hline ITS2 & & & & \\
\hline ITS3 & & & & \\
\hline ITS4 & & $0.229^{\mathrm{a}}(\mathrm{P}=0.024)$ & & \\
\hline CS1 & & & $0.281^{\mathrm{a}}(\mathrm{P}=0.005)$ & \\
\hline CS2 & & & $0.265^{\mathrm{a}}(\mathrm{P}=0.015)$ & $0.208^{\mathrm{a}}(\mathrm{P}=0.032)$ \\
\hline CS3 & & & & \\
\hline EIT1 & & & $0.102^{\mathrm{a}}(\mathrm{P}=0.046)$ & \\
\hline EIT2 & & & $0.218^{\mathrm{a}}(\mathrm{P}=0.038)$ & \\
\hline EIT3 & & & & \\
\hline
\end{tabular}

a) $\mathrm{p}<0.05$

Therefore, IS and IM scales has a weak positive correlation, and IM3 shows a positive agreement with most of the elements of IS scale.

RQ2: Whether there is a relation between the students' perception on the intellectual stimulation and the deep learning approach measurements?

To answer this RQ, the data is gathered on the students' understanding on the intellectual stimulation scale (Bolkan and Goodboy, 2010). Similarly, SETLQ (ETL Project, 2005) is used to gather data on students' perceptions on the deep learning approach. Pearson's product-moment correlation coefficient is used to explore the correlation between the IS and DLA variables. The results show a statistically significant $(\mathrm{p}=0.001)$ and a moderate positive correlation. Pearson's product-moment correlation coefficient is $r=0.585(\alpha=0.05)$ (as shown in Table 3 ). It shows that higher IS scale is associated with higher DLA scale.

Table 3: Correlation between the intellectual stimulation and the intrinsic motivation using Pearson's Product-Moment test

\begin{tabular}{|l|l|r|}
\hline & \multicolumn{2}{c}{$\begin{array}{c}\text { Deep Learning Ap- } \\
\text { proach }\end{array}$} \\
Intellectual Stimulation & Pearson Correlation & $.585^{* *}$ \\
Sig. (2-tailed) & .000 \\
$* *$. Correlation is significant at the 0.01 level (2-tailed).
\end{tabular}


Chowdhry, S. Osowska, R.

Second, Kendall's tau-c test is used to find the measure of agreement between the individual elements of IS and DLA scales, as both are ordinal data type with different number of response choices Kendall's tau-c agreement coefficient for pair of elements is shown in Table 4, with $\alpha=0.05(-1 \leq \tau \leq 1$; where -1 means a perfect disagreement, 0 means both variables are independent and 1 means a perfect agreement). The result shows a statistically significant $(\mathrm{p}<\alpha)$ and a moderate positive agreement between most of the elements of IS and DLA variables. It shows that except ITS2 and DLA9, all the elements of IS and IM scales are in positive agreement with each other.

Table 4: Measure of association between the intellectual stimulation scale data and the deep learning approach data using Kendall's tau-c test

\begin{tabular}{|c|c|c|c|c|c|c|c|c|c|}
\hline & DLA1 & DLA2 & DLA3 & DLA4 & DLA5 & DLA6 & DLA7 & DLA8 & $\begin{array}{l}\text { DLA } \\
9\end{array}$ \\
\hline ITS1 & $\begin{array}{l}0.314^{\mathrm{b}} \\
(\mathrm{P}=0.001)\end{array}$ & $\begin{array}{l}0.214^{\mathrm{b}} \\
(\mathrm{P}=0.02)\end{array}$ & & & $\begin{array}{l}0.269^{\mathrm{b}} \\
(\mathrm{P}=0.001)\end{array}$ & & & & \\
\hline ITS2 & & & & & & & & & \\
\hline ITS3 & $\begin{array}{l}0.274^{\mathrm{b}} \\
(\mathrm{P}=0.002)\end{array}$ & $\begin{array}{l}0.264^{b} \\
(\mathrm{P}=0.005)\end{array}$ & & $\begin{array}{l}0.212^{\mathrm{b}} \\
(\mathrm{P}=0.03)\end{array}$ & $\begin{array}{l}0.255^{\mathrm{b}} \\
(\mathrm{P}=0.001)\end{array}$ & $\begin{array}{l}0.197^{\mathrm{b}} \\
(\mathrm{P}=0.021)\end{array}$ & & & \\
\hline ITS4 & $\begin{array}{l}0.265^{\mathrm{b}} \\
(\mathrm{P}=0.002)\end{array}$ & $\begin{array}{l}0.273^{\mathrm{b}} \\
(\mathrm{P}=0.002)\end{array}$ & $\begin{array}{l}0.191^{\mathrm{b}} \\
(\mathrm{P}=0.036)\end{array}$ & $\begin{array}{l}0.217^{\mathrm{b}} \\
(\mathrm{P}=0.032)\end{array}$ & $\begin{array}{l}0.266^{\mathrm{b}} \\
(\mathrm{P}=0.001)\end{array}$ & $\begin{array}{l}0.261^{\mathrm{b}} \\
(\mathrm{P}=0.002)\end{array}$ & & $\begin{array}{l}0.231^{\mathrm{b}} \\
(\mathrm{P}=0.017)\end{array}$ & \\
\hline $\mathrm{CS} 1$ & $\begin{array}{l}0.247^{\mathrm{b}} \\
(\mathrm{P}=0.01)\end{array}$ & $\begin{array}{l}0.282^{\mathrm{b}} \\
(\mathrm{P}=0.001)\end{array}$ & $\begin{array}{l}0.291^{\mathrm{b}} \\
(\mathrm{P}=0.002)\end{array}$ & $\begin{array}{l}0.276^{\mathrm{b}} \\
(\mathrm{P}=0.005)\end{array}$ & $\begin{array}{l}0.313^{\mathrm{b}} \\
(\mathrm{P}=0.001)\end{array}$ & & $\begin{array}{l}0.194^{\mathrm{b}} \\
(\mathrm{P}=0.025)\end{array}$ & & \\
\hline $\mathrm{CS} 2$ & $\begin{array}{l}0.340^{\mathrm{b}} \\
(\mathrm{P}=0.001)\end{array}$ & $\begin{array}{l}0.265^{\mathrm{b}} \\
(\mathrm{P}=0.003)\end{array}$ & $\begin{array}{l}0.304^{\mathrm{b}} \\
(\mathrm{P}=0.003)\end{array}$ & $\begin{array}{l}0.28^{\mathrm{b}} \\
(\mathrm{P}=0.005)\end{array}$ & $\begin{array}{l}0.301^{\mathrm{b}} \\
(\mathrm{P}=0.001)\end{array}$ & $\begin{array}{l}0.229^{\mathrm{b}} \\
(\mathrm{P}=0.028)\end{array}$ & $\begin{array}{l}0.262^{\mathrm{b}} \\
(\mathrm{P}=0.001)\end{array}$ & $\begin{array}{l}0.242^{\mathrm{b}} \\
(\mathrm{P}=0.023)\end{array}$ & \\
\hline $\mathrm{CS} 3$ & $\begin{array}{l}0.259^{\mathrm{b}} \\
(\mathrm{P}=0.003)\end{array}$ & $\begin{array}{l}0.349^{\mathrm{b}} \\
(\mathrm{P}=0.001)\end{array}$ & $\begin{array}{l}0.231^{\mathrm{b}} \\
(\mathrm{P}=0.021)\end{array}$ & & $\begin{array}{l}0.201^{\mathrm{b}} \\
(\mathrm{P}=0.02)\end{array}$ & $\begin{array}{l}0.221^{\mathrm{b}} \\
(\mathrm{P}=0.017)\end{array}$ & $\begin{array}{l}0.229^{\mathrm{b}} \\
(\mathrm{P}=0.006)\end{array}$ & & \\
\hline EIT1 & $\begin{array}{l}0.361^{\mathrm{b}} \\
(\mathrm{P}=0.001)\end{array}$ & $\begin{array}{l}0.23^{\mathrm{b}} \\
(\mathrm{P}=0.015)\end{array}$ & $\begin{array}{l}0.239^{\mathrm{b}} \\
(\mathrm{P}=0.019)\end{array}$ & $\begin{array}{l}0.311^{\mathrm{b}} \\
(\mathrm{P}=0.006)\end{array}$ & $\begin{array}{l}0.356^{\mathrm{b}} \\
(\mathrm{P}=0.001)\end{array}$ & $\begin{array}{l}0.272^{\mathrm{b}} \\
(\mathrm{P}=0.003)\end{array}$ & $\begin{array}{l}0.177^{\mathrm{b}} \\
(\mathrm{P}=0.04)\end{array}$ & & \\
\hline EIT2 & $\begin{array}{l}0.352^{\mathrm{b}} \\
(\mathrm{P}=0.001)\end{array}$ & $\begin{array}{l}0.293^{\mathrm{b}} \\
(\mathrm{P}=0.001)\end{array}$ & $\begin{array}{l}0.372^{\mathrm{b}} \\
(\mathrm{P}=0.001)\end{array}$ & $\begin{array}{l}0.46^{\mathrm{b}} \\
(\mathrm{P}=0.001)\end{array}$ & $\begin{array}{l}0.386^{\mathrm{b}} \\
(\mathrm{P}=0.001)\end{array}$ & $\begin{array}{l}0.273^{\mathrm{b}} \\
(\mathrm{P}=0.002)\end{array}$ & & $\begin{array}{l}0.221^{\mathrm{b}} \\
(\mathrm{P}=0.035)\end{array}$ & \\
\hline EIT3 & $\begin{array}{l}0.298^{\mathrm{b}} \\
(\mathrm{P}=0.001)\end{array}$ & $\begin{array}{l}0.206^{\mathrm{b}} \\
(\mathrm{P}=0.036)\end{array}$ & $\begin{array}{l}0.306^{\mathrm{b}} \\
(\mathrm{P}=0.001)\end{array}$ & $\begin{array}{l}0.232^{\mathrm{b}} \\
(\mathrm{P}=0.024)\end{array}$ & & $\begin{array}{l}0.261^{\mathrm{b}} \\
(\mathrm{P}=0.005)\end{array}$ & & $\begin{array}{l}0.256^{\mathrm{b}} \\
(\mathrm{P}=0.01)\end{array}$ & \\
\hline
\end{tabular}

b) p $<0.05$

Therefore, IS and DLA scales have a moderate positive correlation, and most of the elements of both the scales have a weak positive agreement with each other. 


\section{DISCUSSION}

The RQ1 results show a positive agreement of intrinsic motivation (IM3) with intellectual stimulation (CS1, CS2, EIT1 and EIT2) (Appendix 1). Therefore, the data suggests that to stimulate the students intellectually, they need to be challenged to on how well they know the material (CS2). The course content should test the students understanding (CS1), helping them to think deeply about the concepts taught in the class (EIT1) and come to their conclusions about the course content (EIT2). As a result of such a challenge, students get an opportunity to understand the course content as thoroughly as possible (IM3), which further intrinsically motivates the students. Therefore, the lecturers may design learning activities that provide a challenging learning environment which wants students to work hard, develop self-directed learning (SDL) (Krouk and Zhuravleva, 2009) skills, think deeply about the ideas, construct new knowledge and engage in a self-evaluation. There should be provision for adequate studentlecturer interaction opportunities, to give timely feedback to the students. To give feedback, a lecturer may also adopt verbal strategies such as asking questions, summarising and suggesting alternatives (Savin-Baden, 2003). Similarly, lectures may adopt interactive teaching methods based on the students' different learning styles, to encourage students to take part in the learning actively. For instance, the teaching methods may use Kolb's learning cycle (Lu, Jia, Gong and Clark, 2007) to classify learners into four categories such as divergers, assimilators, convergers and accommodators. These classes will further help the lecturers in adopting suitable teaching strategies and, customise teaching according to the students' needs. For example, those identified as divergers prefer hands-on exploration, followed by productive feedback and the assimilators prefer lectures, experiments and the use of conceptual models to understand the topic. As a result, it will help students to understand the course content and will encourage them to take responsibility for their studies.

The RQ2 result shows that IS and DLA scales have moderate positive correlation and most of the elements of both the scales show a positive agreement among themselves. As a result, intellectually stimulating students will encourage them to adopt deep learning approach. To intellectually stimulate the students, lecturers may select interactive teaching styles by providing unique learning activities to get the class involved with the course content (ITS1). The unique learning activities can be designed according to the students learning styles, are related to the real-life content (DLA2) and will help set off the long chain of thoughts (DLA1). Secondly, lecturers may encourage students' active participation in the classroom activities (ITS3) and encourage them to see reasons behind the thing (DLA6) and make their conclusions about what
In Search of

Intellectual

Stimulation:

Understanding the Relationship

Between

Motivation, Deep

Learning and

Stimulation in the Higher Education

Classroom 
Chowdhry, S. Osowska, R.

they are studying (DLA4). Thirdly, the learning activities should get students involved in the learning process in a variety of ways (ITS4) and encourage them to think critically about what they are learning (EIT3). As a result, it will help students in developing skills of asking questions such as 'What author exactly meant (DLA8) and evaluated their reasoning to see if it makes sense (DLA3). The new proposed teaching and learning strategy using intellectual scale are shown in Table 5 below.

Table 5: Mapping of intellectual scale with teaching and learning activities

\begin{tabular}{|l|l|}
\hline $\begin{array}{l}\text { Intellectual } \\
\text { Stimulation } \\
\text { Scale }\end{array}$ & Teaching \& Learning activities \\
\hline ITS1 & $\begin{array}{l}\text { 1. } \\
\text { Use of screencasts to teach software (visual \& auditory learning/ } \\
\text { assimilators). }\end{array}$ \\
$\begin{array}{l}\text { Demonstrations in the classroom on taking measurements (visu- } \\
\text { al \& auditory learning). } \\
\text { Students hands on experience of taking measurements (kinaes- } \\
\text { thetic learning/divergers). }\end{array}$ \\
\hline ITS4 & $\begin{array}{l}\text { 1. } \\
\text { Students provided information on usefulness of active participa- } \\
\text { tion in learning. } \\
\text { Students provided collaborative learning opportunities in the } \\
\text { classroom. }\end{array}$ \\
\hline CS1 & $\begin{array}{l}\text { Students provided self-directed learning opportunities in the } \\
\text { classroom. }\end{array}$ \\
\hline CS2 & Learning activities designed to challenge students. \\
\hline EIT1 & $\begin{array}{l}\text { Learning activities designed to encourage students to work hard. } \\
\text { about the concepts. }\end{array}$ \\
\hline EIT2 & $\begin{array}{l}\text { Collaborative learning opportunities provided to help students in } \\
\text { construction of new knowledge. }\end{array}$ \\
\hline EIT3 & $\begin{array}{l}\text { Students provided opportunities to critically analyse the work to con- } \\
\text { struct new knowledge. }\end{array}$ \\
\hline
\end{tabular}

The new proposed teaching and learning strategy is implemented and students feedback (Appendix 2) on their learning experience is as follows, 


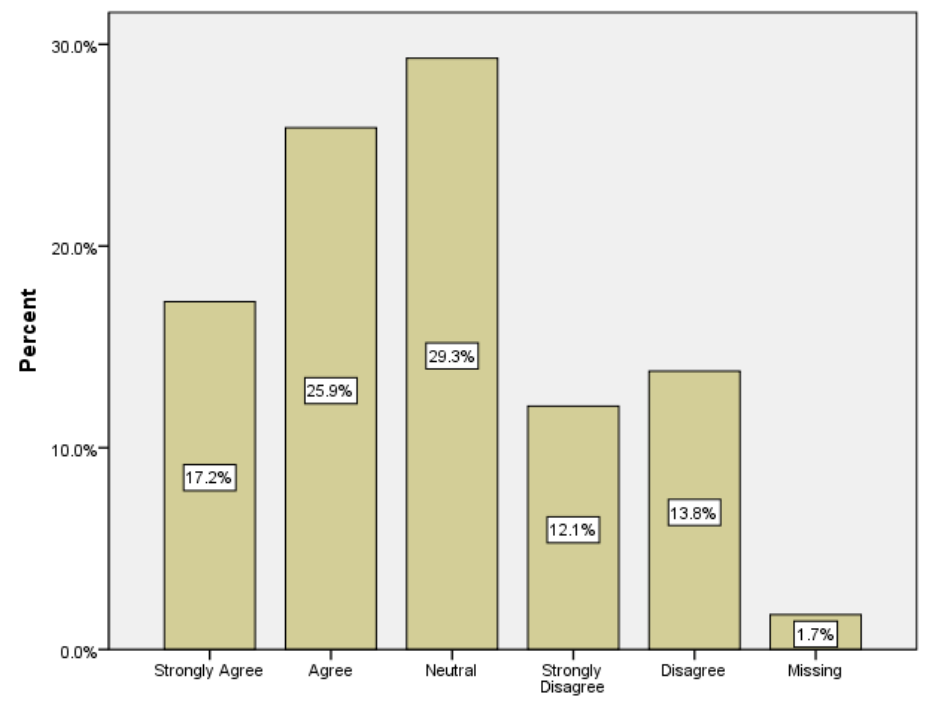

In Search of

Intellectual

Stimulation:

Understanding the Relationship

Between

Motivation, Deep

Learning and

Stimulation in the

Higher Education

Classroom

Figure 2: Online videos and demonstrations helped in learning and understanding

The figure 2 shows that $43.1 \%$ of students at least agreed that online videos and demonstrations helped them in learning and understanding the course content.

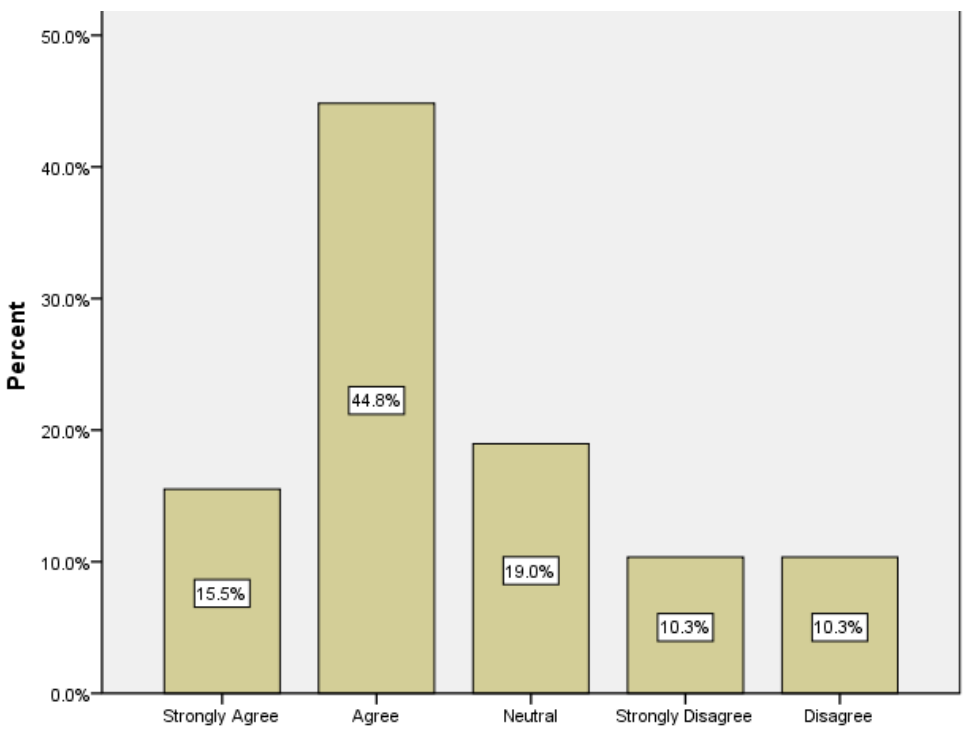

Figure 3: Hands on measurement improved learning experience 
Chowdhry, S. Osowska, R.
The figure 3 shows that $60.3 \%$ of students at least agreed that using Vernier Calliper and Micrometre to take mechanical measurements before making engineering drawings on Computer Aided Engineering (CAD) software improved their learning experience.

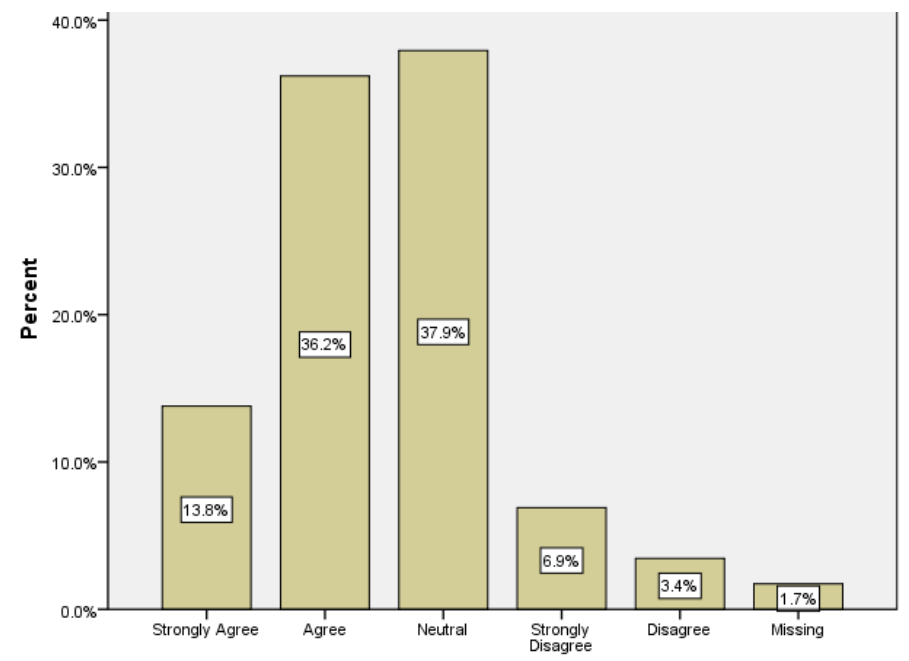

Figure 4: I felt motivated as learning activities required active participation The figure 4 shows that $50 \%$ of students at least agreed that the requirement of active participation in the learning activities motivated them to study.

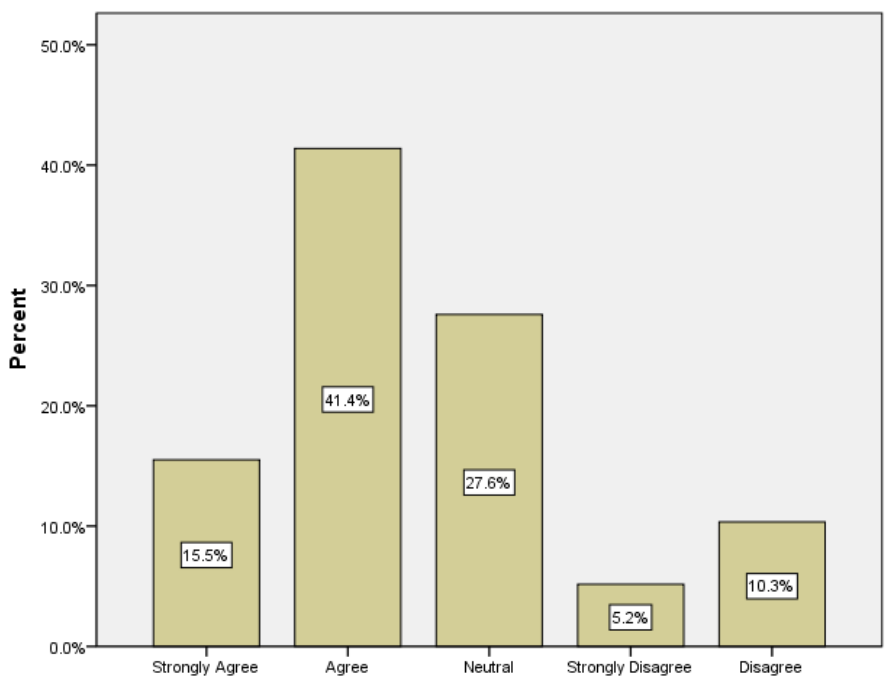

Figure 5: Collaborative learning helped in completing the design solution 
The figure 5 shows that $56.9 \%$ of students at least agree that opportunities to do collaborative learning helped them in finding the design problem solution.

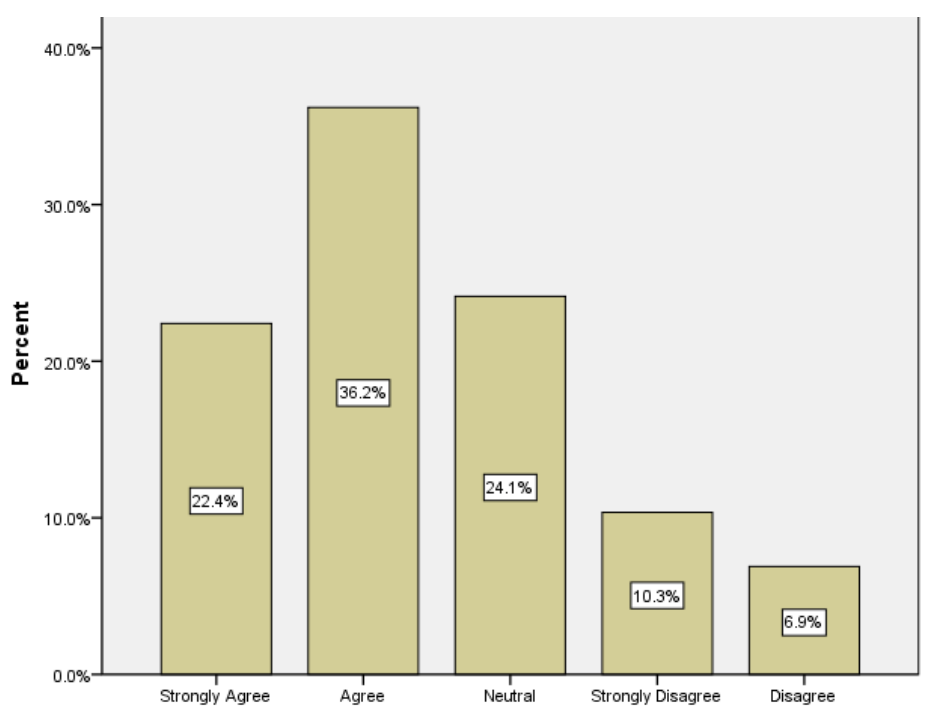

Figure 6: Learning activity provided opportunities for self-directed learning The figure 6 suggests that $58.6 \%$ of students at least agreed that learning activity design encouraged them to do self-directed learning.

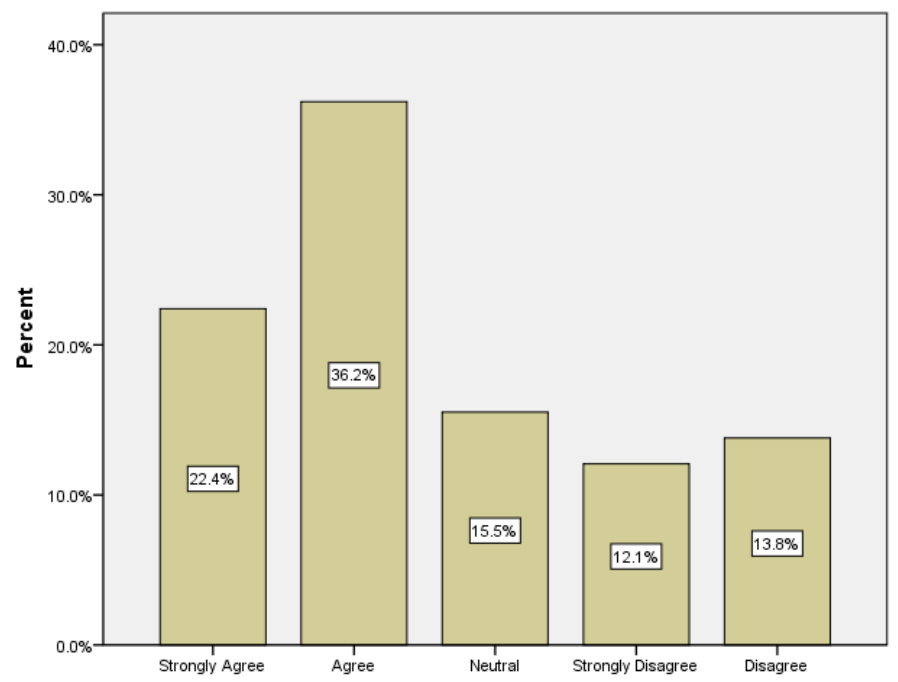

Figure 7: Learning activity challenged me
In Search of Intellectual Stimulation: Understanding the Relationship Between Motivation, Deep Learning and Stimulation in the Higher Education Classroom 
Chowdhry, S. Osowska, R.
The figure 7 shows that $58.6 \%$ of students at least agreed that learning activity challenged them in the learning and understanding the module content.

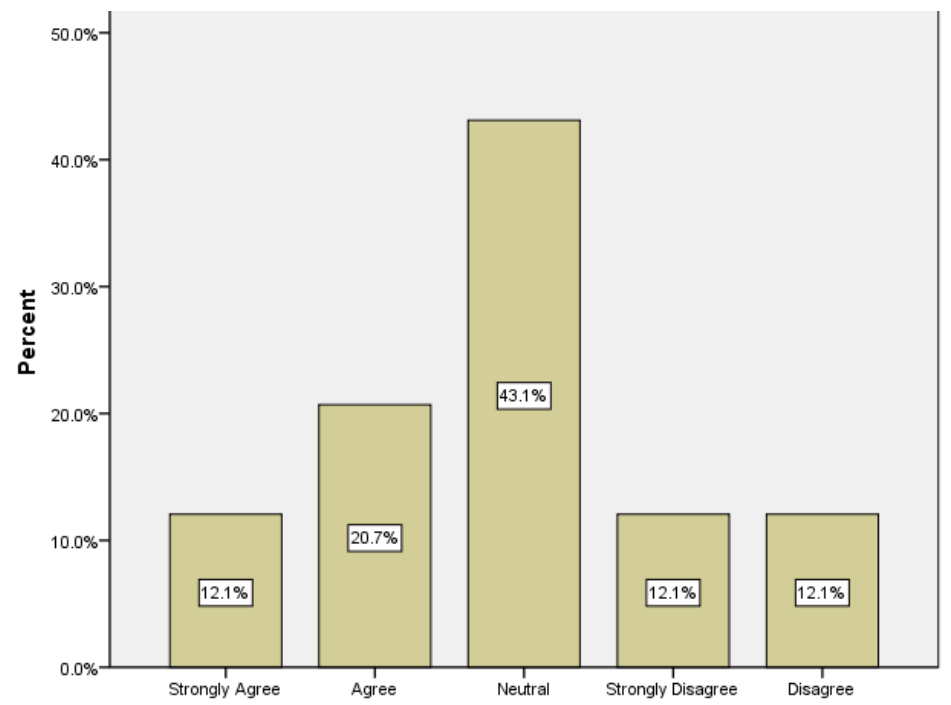

Figure 8: Learning activity encouraged me to work hard

The figure 8 indicates that $32.8 \%$ of students at least agreed that learning activity encouraged them to work hard in studying the module content.

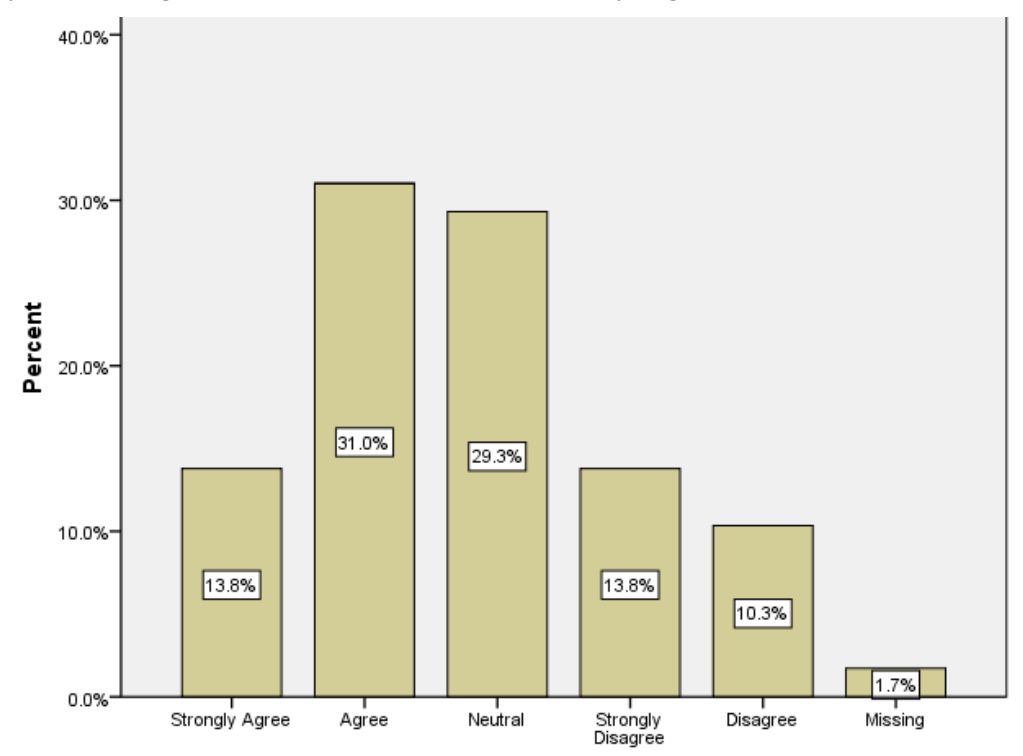

Figure 9: Learning activity encouraged me to think deeply about the concept 
The figure 9 suggests that $44.8 \%$ of students at least agreed that learning activity encouraged them to adopt deep learning approach in understanding the module content.

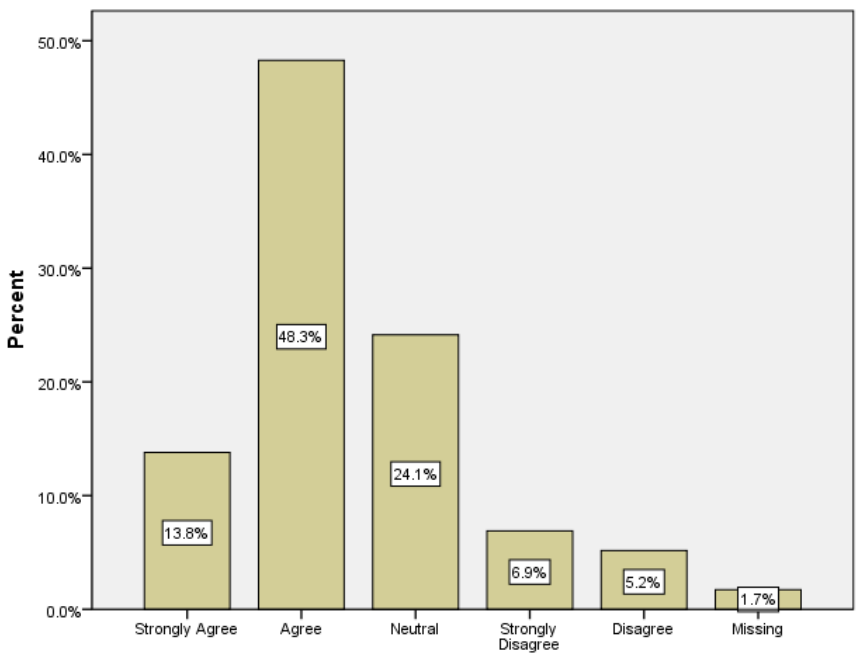

Figure 10: Collaborative learning helped in constructing new knowledge The figure 10 shows that $62.1 \%$ of students at least agreed that collaborative learning opportunities helped them in constructing new knowledge from the module content.

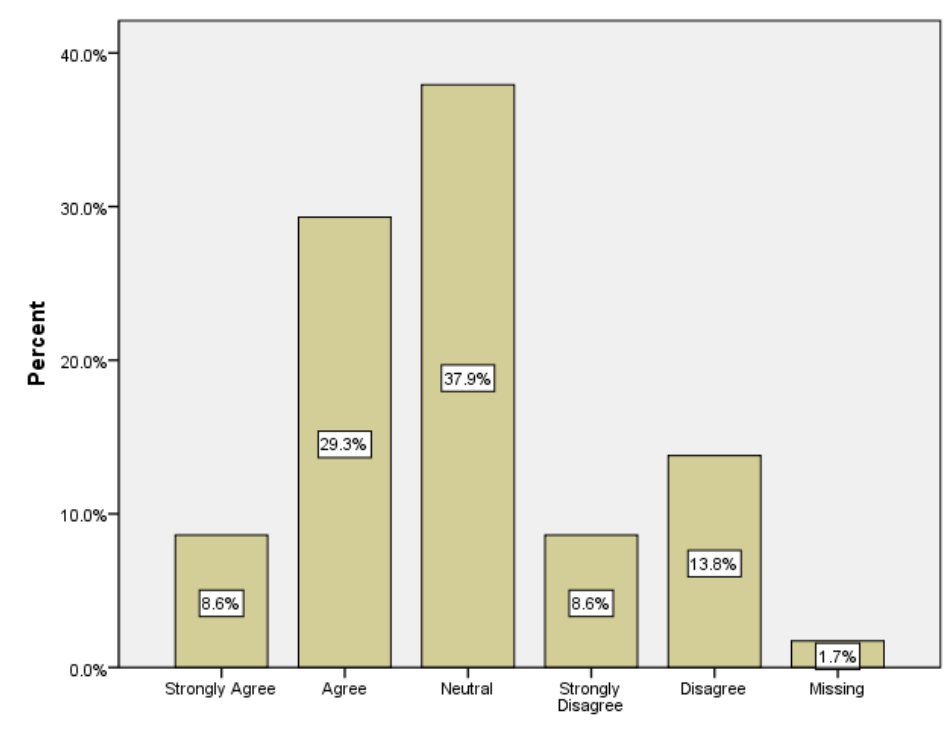

Figure 11: Critical analysis of the concepts helped in constructing new knowledge
In Search of Intellectual Stimulation: Understanding the Relationship Between Motivation, Deep Learning and Stimulation in the Higher Education Classroom 
Chowdhry, S. The figure 11 indicates that $37.9 \%$ of students at least agreed that opportunities Osowska, R. to do the critical analysis of the academic content helped them in constructing new knowledge.

The result suggests that the new intellectual scale based teaching and learning strategy is useful in intellectually stimulated the students and in providing improved learning experience. The variety of the teaching methods used considers different learning styles. It helped students to participate in the learning actively, to do self-directed learning, perform critical analysis and adopt deep learning approach in understanding the module content, and in the construction of new knowledge.

The use of an Intellectual stimulation scale will help the institution to specifically focus on the areas of teaching and learning such as students learning styles, Kolb's learning cycle and self-directed learning (SDL), to provide students with an intellectually stimulating learning environment. To use an intellectual stimulation scale as an evaluation criterion for teaching and learning in the higher education institution, a separate questionnaire could be designed to collect information on different elements of an intellectual stimulation scale.

Taking this idea further, academic staff could organise workshops to raise awareness about how to use the intellectual stimulation scale to improve the students learning experience. The institutions may give new lecturer's information on the importance of providing students with an intellectually stimulating environment during the induction training programme. Students' union may also be encouraged to organise events to make students familiar with the intellectual stimulation scale. Academic services may also help staff to consider using an intellectual stimulation scale while designing and changing their module descriptors to meet student needs better' and increase levels of intellectual stimulation in the classroom.

\section{CONCLUSION}

The aim of this study was to investigate the intellectual stimulation, intrinsic motivation and deep learning approach relative to students' perception. In particular, the current study had three objectives: 1) to determine the relationship between the students' perceptions on intrinsic motivation, intellectual stimulation and deep learning approach, 2) to find out what intervention strategies lecturers can put in place to support students feeling 'intellectually stimulated', 3) propose recommendation for using 'intellectual stimulation' as an evaluation criterion for teaching and learning in higher education institutions and the engineering classroom. The study has found a statistically significant, weak positive correlation between the IS and IM 
scales. The IM3 element is in positive agreement with CS1, CS2, EIT1 and EIT2 elements of the IS scale. Second, there is a statistically significant, moderate positive correlation between IS and DLA scales. Except ITS2 and DLA9, all the elements of IS and IM scales are in positive agreement with each other. Third, the students feedback suggests that implementation of the new intellectual scale based teaching and learning strategy is useful in intellectually stimulated the students and helped them to actively participate in the learning, to do self-directed learning, perform critically analysis and in adopting deep learning approach in understanding the module content, and in construction of new knowledge.

The main findings therefore are, to intellectually stimulate the students, the learning activities should encourage them to engage in deep learning to ensure that they really know the material well. The course content should challenge the students, helping them to reflect deeply upon the concepts taught in the HE class and draw their own conclusions about the course content. In doing so, it will also intrinsically motivate the students and provide them with an opportunity to understand the course content thoroughly. Therefore, the lecturers should design the learning activities that facilitate a challenging learning environment motivating students to, develop SDL skills, think deeply, construct new knowledge and engage in the process of self-evaluation. By acknowledging students learning styles, interactive teaching methods could encourage students' active participation in the learning. Furthermore, lecturers should provide timely feedback to the students.

The research limits to the generalisability of this study to the modules across the university are small sample size, lack of control groups and variables present with intellectually stimulated and non-stimulated learning. However, the results of the study will be transferable for the different departments across the university in understanding the intellectual stimulation scale. Similarly, it will further help in improving the teaching and learning practice in the university.

Collection of information on different elements of the intellectual stimulation scale may help to find out the feasibility of using the intellectual stimulation scale as an evaluation criteria for teaching and learning in higher education institution

It implies that the educational institutions may make a strategy to systematically ingrain the idea of IS scale in its courses. For instance, spreading awareness among the academic staff about how to use the IS scale to improve the students learning experience. The new lecturer's induction training programme can also incorporate information on using IS scale to enhance the students learning experience. The departmental quality committees may
In Search of Intellectual Stimulation: Understanding the Relationship Between Motivation, Deep Learning and Stimulation in the Higher Education Classroom 
Chowdhry, S. Osowska, R.

encourage staff to consider the IS scale while designing and changing the module descriptors. The Students' union could also contribute by organising events to make students familiar with the intellectual stimulation scale.

A suggested further research is to compare the effect of setting in IST, CS and EIT elements of intellectual stimulation scale in different modules in the School of Engineering.

\section{ACKNOWLEDGEMENTS}

The authors would like to thank Dr Jacqueline Brodie for the helpful comments on an earlier draft.

\section{REFERENCES}

1. Bolkan, S., Goodboy, A.K. \& Griffin, D.J., (2011) "Teacher Leadership and Intellectual Stimulation: Improving Students" Approaches to Studying through Intrinsic Motivation. Communication Research Reports, 28(4), pp. 337-346. http://dx.doi.org/10.1080/088240 96.2011.615958.

2. Bolkan, S., Goodboy, A.K. (2012) Behavioral indicators of transformational leadership in the college classroom. http://dx.doi.org/10.1080/17459435.2011.601520.

3. Bolkan,S. \& Goodboy, A.K. (2010) "Transformational Leadership in the Classroom: The Development and Validation of the student Intellectual Stimulation Scale" Communication Reports, 23(2), pp. 91-105. http://dx.doi.org/10.1080/08934215.2010.511399.

4. Chavan,A. A., Khandagale, V. S. (2014) "Development of Critical Thinking Skill Programme for the Student Teachers of Diploma in Teacher Education colleges", Issues and Ideas in Education, 2(1), pp.25-37.

5. Duff, A. (2003) "Quality of learning on an MBA programme: The impact of approaches to learning on academic performance", Educational Psychology, 23, pp.123-139. http:// dx.doi.org/10.1080/01443410303230.

6. Duff, A. (2004) "The Revised Approaches to Studying Inventory (RASI) and its use in management education", Active learning in higher education, 5, pp.56-72.

7. Edinburgh Napier University (2013) "National Student Survey Update Report: "Areas for Improvement.” Available at: http://staff.napier.ac.uk/services/hr/development/acprofdev/ PL/Documents/NSS improvement 2013 _FINAL COPY.pdf.

8. Edinburgh Napier University, (2014) NSS website. Available at: http://www. thestudentsurvey.com/the_nss.html [Accessed October 2, 2014].

9. Entwistle, N. (1988) Styles of Learning and Teaching,

10. Entwistle, N., Hanley, M., Hounsell, D. (1979) "Identifying distinctive approaches to studying", Higher Education, 8, pp.365-380.

11. Gupta, S.C., Kapoor, V.K. (2007) "Fundamentals of Applied Statistics", Sultan Chand \& Sons.

12. Hair, J.F., Black, W.C., Babin, B.J., and Anderson, R. E., Hair, J.F., Black, W.C., Babin, B.J., and Anderson, R. E. (2009) "Multivariate Data Analysis - A Global Perspective", New Jersey: Pearson Education Inc.

13. Hetland, H., Sandal, G. (2003) "Transformational leadership in Norway; outcome and personality correlate", European Journal of Work and Organizational Psychology, 12(2), pp.147-170. http://dx.doi.org/10.1080/13594320344000057.

14. Krouk, B.I., Member, S. \& Zhuravleva, O.B. (2009) "Dynamic Training Elements in a Circuit Theory Course to Implement a Self-Directed Learning Process", , 52(3), pp.394399. http://dx.doi.org/10.1109/TE.2008.930091. 
15. Lu, H. et al. (2007) "The Relationship of Kolb Learning Styles, Online Learning Behaviors and Learning Outcomes", Educational Technology \& Society, 10(4), pp.187-196.

16. Pintrich, Paul, R. et al., (1991) "Manual for the Use of the Motivated Strategies for Learning Questionnaire”, (MSLQ)., p.75.

17. Project, E., (2005) "Shortened Experiences of Teaching and Learning Questionnaire ( SETLQ ). , 44, pp.1-3.

18. Prosser, M.,Trigwell, K. (1999) "Understanding learning and teaching: The experience in highereducation", Milton Keynes, England: SRHE,Open University Press.

19. Savin-Baden, M.(2003) "Facilitating Problem-based Learning: Illuminating perspectives", Buckingham: SRHE/Open University Press.

20. Shahzad, S., Zareen, H. (2011) "Perception of intellectual stimulation, creativity and innovation among health managers working in tertiary level hospitals", Journal of Ayub Medical College Abbottabad, 23(3), pp.86-90.

21. Wolters, C. A. (1998) "Self-regulated learning and college students' regulation of motivation", Journal of Educational Psychology, 90, pp.224-235. http://dx.doi. org/10.1037/0022-0663.90.2.224
In Search of Intellectual Stimulation: Understanding the Relationship Between Motivation, Deep Learning and Stimulation in the Higher Education Classroom 
Chowdhry, S.

Osowska, R.

\section{APPENDICES}

\section{APPENDIX 1: Quantitative feedback questionnaire}

\begin{tabular}{|c|c|c|}
\hline ITS1 & $\begin{array}{l}\text { Unique activities are used to get the class involved with the } \\
\text { course material. }\end{array}$ & $\begin{array}{l}\text { (1-Never '7-Al- } \\
\text { ways) } \\
1234567\end{array}$ \\
\hline ITS2 & Exciting teaching techniques are used in class. & 1234567 \\
\hline ITS3 & $\begin{array}{l}\text { Helps students get excited about learning through classroom } \\
\text { activities. }\end{array}$ & 1234567 \\
\hline ITS4 & $\begin{array}{l}\text { Teaching stimulates students to help them get involved in the } \\
\text { learning process in a variety of ways }\end{array}$ & 1234567 \\
\hline $\mathrm{CS} 1$ & Challenges me to be the best student I can be. & 1234567 \\
\hline $\mathrm{CS} 2$ & $\begin{array}{l}\text { Makes me work hard to ensure that I really know the material } \\
\text { well. }\end{array}$ & 1234567 \\
\hline $\mathrm{CS} 3$ & Helps me realise that my hard work is worth it. & 1234567 \\
\hline EIT1 & Helps me think deeply about the concepts taught in class. & 1234567 \\
\hline EIT2 & $\begin{array}{l}\text { Encourages me to come to my own conclusions about course } \\
\text { material. }\end{array}$ & 1234567 \\
\hline EIT3 & Wants me to think critically about what we are learning. & 1234567 \\
\hline DLA1 & $\begin{array}{l}\text { Ideas I've come cross in my academic reading often set off } \\
\text { long chains of thought. }\end{array}$ & $\begin{array}{l}\text { (1-Rarely true; } \\
\text { 5- Usually true) } \\
\begin{array}{llllll}1 & 2 & 3 & 4 & 5\end{array}\end{array}$ \\
\hline DLA2 & $\begin{array}{l}\text { In making sense of new ideas, I have often related them to } \\
\text { practical or real life contexts. }\end{array}$ & $\begin{array}{lllll}1 & 2 & 3 & 4 & 5\end{array}$ \\
\hline DLA3 & $\begin{array}{l}\text { I have been over the work I have done to check my reasoning } \\
\text { and see that it makes sense. }\end{array}$ & $\begin{array}{lllll}1 & 2 & 3 & 4 & 5\end{array}$ \\
\hline DLA4 & $\begin{array}{l}\text { I have looked at evidence carefully to reach my own conclu- } \\
\text { sion about what I am studying. }\end{array}$ & $\begin{array}{lllll}1 & 2 & 3 & 4 & 5\end{array}$ \\
\hline DLA5 & $\begin{array}{l}\text { When I have been communicating ideas, I have thought over } \\
\text { how well I have got my points across. }\end{array}$ & \begin{tabular}{lllll|}
1 & 2 & 3 & 4 & 5
\end{tabular} \\
\hline DLA6 & $\begin{array}{l}\text { It has been important for me to follow the argument, or to see } \\
\text { the reasons behind things. }\end{array}$ & $\begin{array}{lllll}1 & 2 & 3 & 4 & 5\end{array}$ \\
\hline DLA7 & $\begin{array}{l}\text { Concentration has not been usually been a problem for me, } \\
\text { unless I have been really tired. }\end{array}$ & $\begin{array}{lllll}1 & 2 & 3 & 4 & 5\end{array}$ \\
\hline DLA8 & $\begin{array}{l}\text { In reading for this course unit, I have tried to find out for my- } \\
\text { self exactly what the author means. }\end{array}$ & $\begin{array}{lllll}1 & 2 & 3 & 4 & 5\end{array}$ \\
\hline
\end{tabular}




\begin{tabular}{|c|c|c|}
\hline DLA9 & $\begin{array}{l}\text { I have not understood things well enough when studying, I } \\
\text { have tried a different approach. }\end{array}$ & $\begin{array}{lllll}1 & 2 & 3 & 4 & 5\end{array}$ \\
\hline IM1 & $\begin{array}{l}\text { In a class like this, I prefer course material that really challeng- } \\
\text { es me so I can learn new things. }\end{array}$ & $\begin{array}{l}\text { (1-Not at all true } \\
\text { of me; } 7 \text { - Very } \\
\text { true of me) } \\
1234567\end{array}$ \\
\hline IM2 & $\begin{array}{l}\text { In a class like this, I prefer course material that arouses my } \\
\text { curiosity, even if it is difficult to learn. }\end{array}$ & 1234567 \\
\hline IM3 & $\begin{array}{l}\text { The most satisfying thing for me in this course is trying to } \\
\text { understand the content as thoroughly as possible. }\end{array}$ & 1234567 \\
\hline IM4 & $\begin{array}{l}\text { When I have the opportunity in this class, I choose course } \\
\text { assignments that I can learn from even if they don't guarantee a } \\
\text { good grade. }\end{array}$ & 1234567 \\
\hline
\end{tabular}

In Search of Intellectual Stimulation: Understanding the Relationship Between Motivation, Deep Learning and Stimulation in the Higher Education Classroom

APPENDIX 2: Students feedback questionnaire on their learning experince

1. I felt motivated by the information provided on the usefulness of active participation.

a) Strongly Agree b) Agree c) Neutral d) Strongly Disagree e) Disagree

2. Collaborative learning helped in completing the design solution.

a) Strongly Agree b) Agree c) Neutral d) Strongly Disagree e) Disagree

3. Collaborative learning helped in constructing new knowledge.

a) Strongly Agree b) Agree c) Neutral d) Strongly Disagree e) Disagree

4. The learning activity provided opportunity to do self-directed learning.

a) Strongly Agree b) Agree c) Neutral d) Strongly Disagree e) Disagree

5. Screencasts and demonstrations helped in the learning.

a) Strongly Agree b) Agree c) Neutral d) Strongly Disagree e) Disagree

6. Hands on experience on measuring/disassembly helped in the learning.

a) Strongly Agree b) Agree c) Neutral d) Strongly Disagree e) Disagree

7. Critical analysis of the work helped in constructing new knowledge.

a) Strongly Agree b) Agree c) Neutral d) Strongly Disagree e) Disagree

8. Learning activity encouraged me to work hard.

a) Strongly Agree b) Agree c) Neutral d) Strongly Disagree e) Disagree

9. Learning activity challenged me.

a) Strongly Agree b) Agree c) Neutral d) Strongly Disagree e) Disagree 